\author{
انتخاب مدل مناسب براى بيشبينى خشكسالى شهر سمنان در مقياس زمانى كوتاه \\ مدت ماهانه با استفاده از آمار هواشناسى و مدلهاى خطى و غير خطيى \\ مريم صادقيان، حجت كرمى * و سيد فرهاد موسوى'

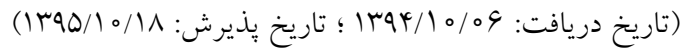

جكيده

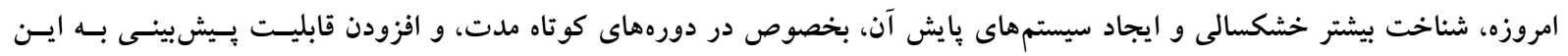

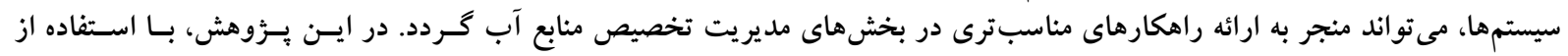

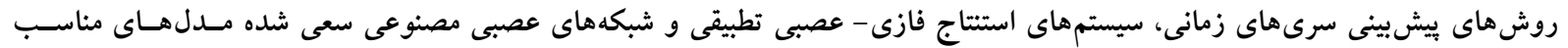

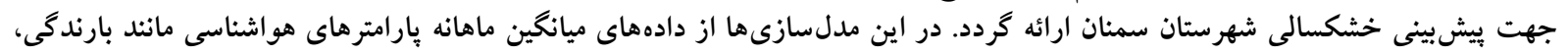

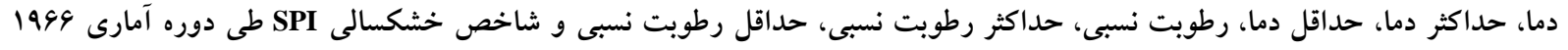

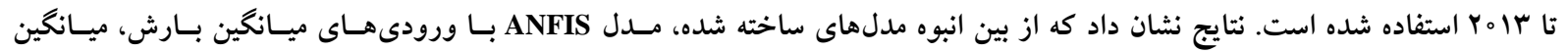

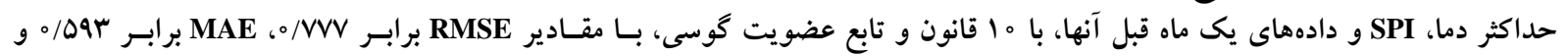

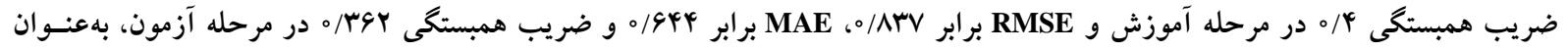

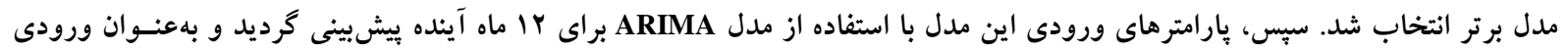

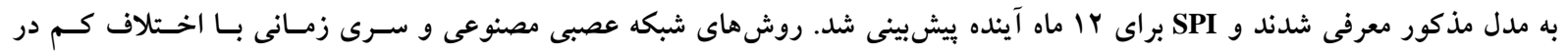

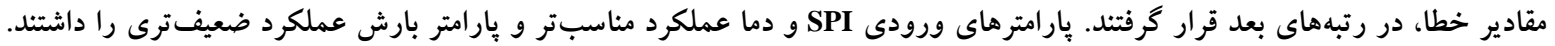

وازمهاى كليدى: ييشينى خشكسالى، سرى زمانى، شبكه عصبى مصنوعى، سيستم استتاج فازى- عصبى تطبيقى

\footnotetext{
ا. كروه مهندسى آب و سازهاى هيدروليكى، دانشكده مهندسى عمران، دانشكاه سمنان

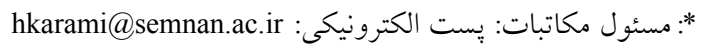


روشهاى تركيبى نسبت به ساير روشها بود.

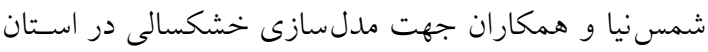

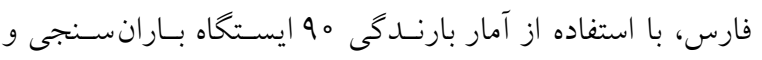

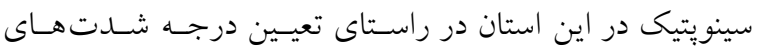
خشكسالى، از شاخص استاندارد شده بارش استفاده كردند (ه).

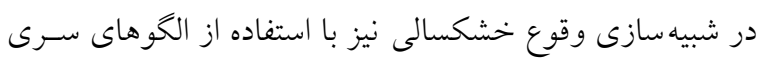

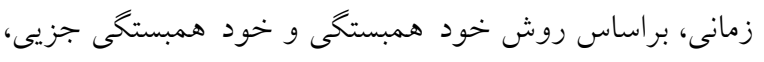

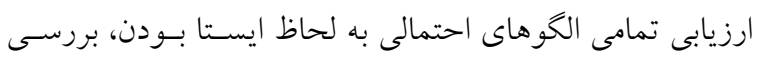

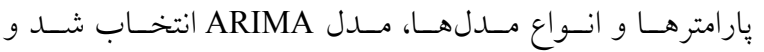
مناسبترين مدل جهت شبيه سـازى خشكسـالى در هـر منطقـه

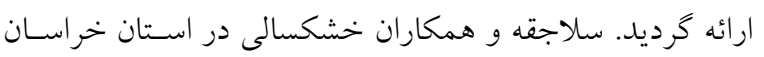

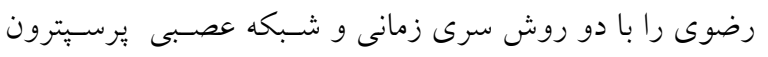

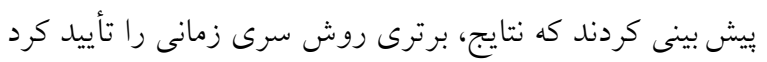

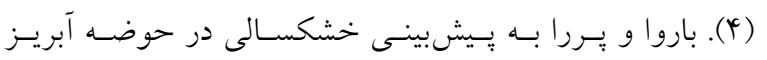

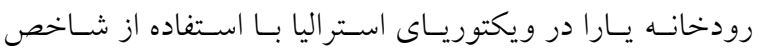
خشكسالى Nonlinear Aggregated Drought Index) NADI)، مدلهاى آمـارى ARIMA و ANN يُرداختنــ (11). درنهايـت،

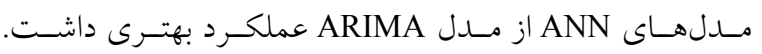
حسين يور نيكنام و همكاران با استفاده از مقادير بيشين شاخص SPI

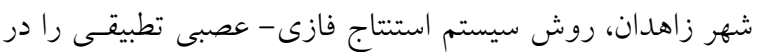
ساخت مدل هاى بيش بينى خشكسالى به كار بردنـــ (سا). نتـايج

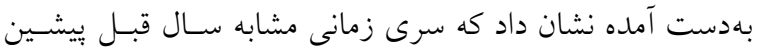
شاخص SPI در بيشبينى خشكسالى هـاى r اماهـه مـؤثرتر از شاخص هاى اقليمى مىباشد. جليلى و همكـاران بـا استفاده از

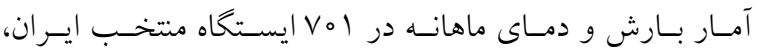
شاخص هـاى خشكسـالى NDVI، NDVI-Dev و TCI VCI و

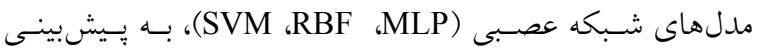

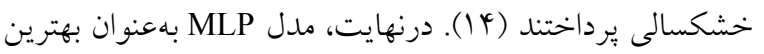
مدل معرفى شد.

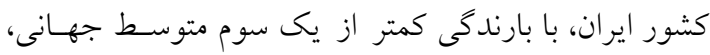

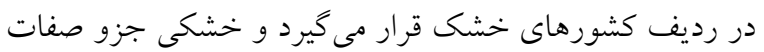

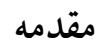

در ادوار مختلف، همواره دسترسى و تأمين منـابع آب يكسى از

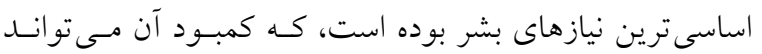

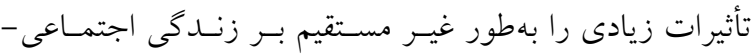

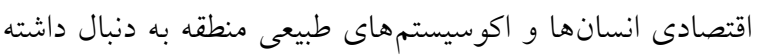

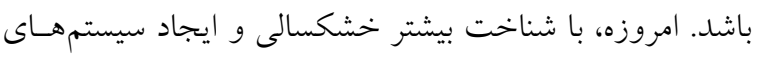

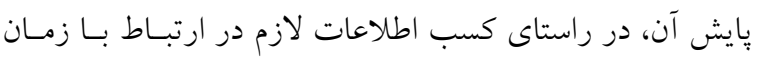
آغاز، خاتمه و شدت خشكسالى در مقياس هاى مختلف زمانى

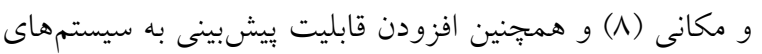

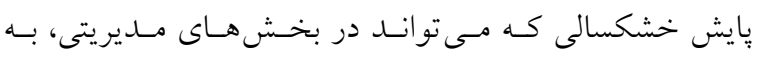

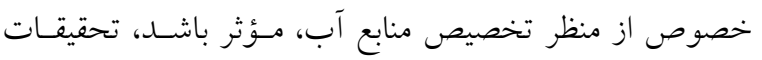

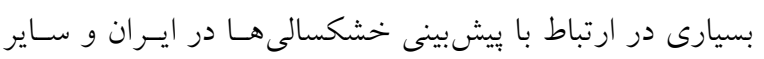

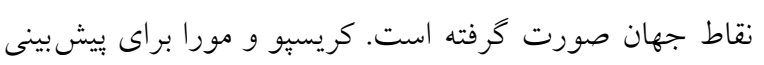

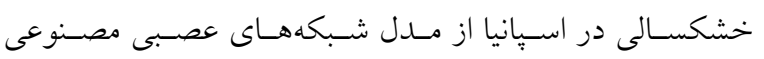

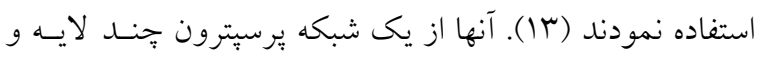

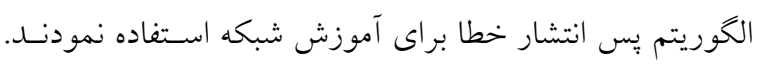

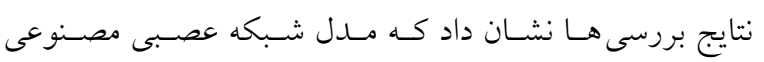

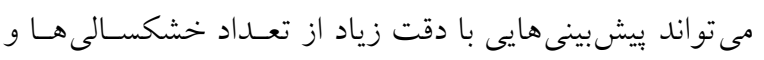

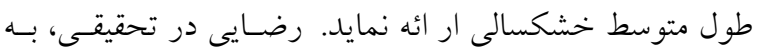
معرفى توانيى هاى روش هاى شبكه عصبى مصـنوعى در حسل

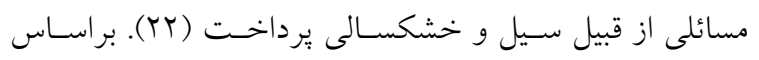

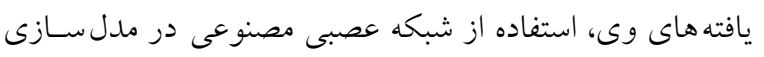

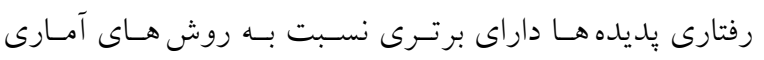

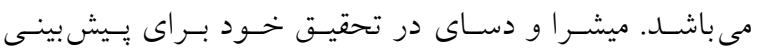

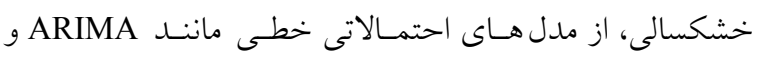

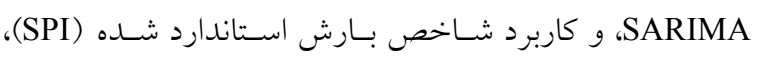

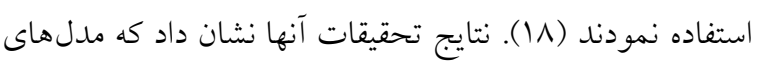

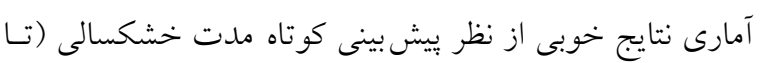

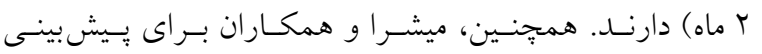

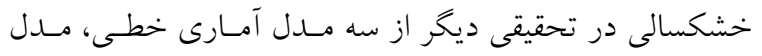

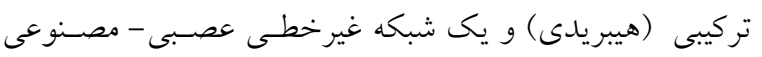

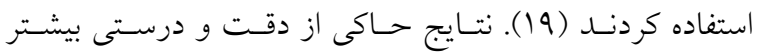




\begin{tabular}{|c|c|c|c|}
\hline بارندكى تابستانى & دوران بارندگى نامشخص است & بارندگى زمستان & مرز مرز \\
\hline $\mathrm{P}=\mathrm{T}+1 \mathrm{k}$ & $\mathrm{P}=\mathrm{T}+\mathrm{V}$ & $\mathrm{P}=\mathrm{T}$ & بيابانى / استبى \\
\hline $\mathrm{P}=\mathrm{r}(\mathrm{T}+\mid \mathrm{Y})$ & $P=r(T+V)$ & $\mathrm{P}=r \mathrm{~T}$ & استيى / مرطوب \\
\hline
\end{tabular}

در رابطه فوق، I= ضريب خشـكى، T= متوسطط دمـاى سـالانه (سانتى گراد) و P= متوسط بارندگى سالانه (ميلى متر ) مس باشـــ (V)

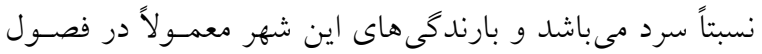

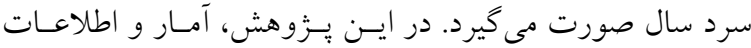
هواشناسى از ايستخاه هواشناسى سينويتيك شهرستان سمنان كه در سال ابץ|| (1990 ميلادى) تأسيس شده، اخذ كرديده است. اين ايستكاه در طول جغرافيايى هاه درجه و بآ دقيقـه شـرقى و عرض جغرافيايى ه广 درجه و بr دقيقـه شـمالى قـرار گرفتـه و

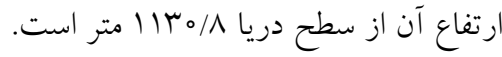
يارامترهـاى مـورد اسـتفاده در ايسن تحقيـق شـامل آمـار و اطلاعات هو اشناسى و شـاخص خشكسـالى بـارش استاندارد SPI بود. شـاخص (SPI: Standardized Precipitation Index)

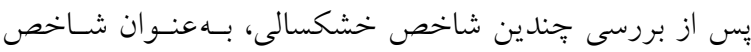

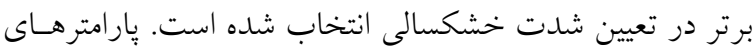

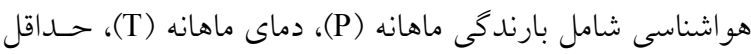

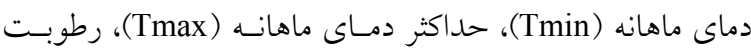

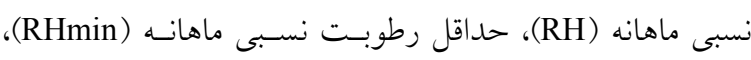

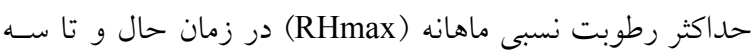

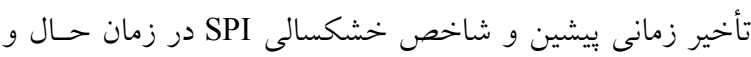

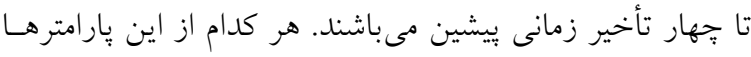

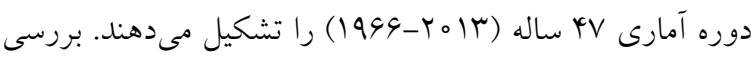

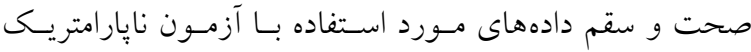

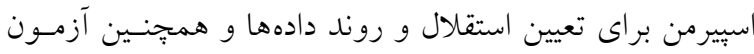

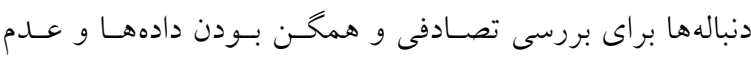

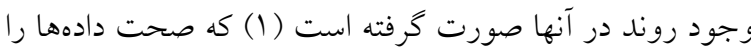
تأييد مى كنند.
ذاتى آن محسوب مىشود. وضعيت اقليم و تأثير خشكسـالىهـا بر استانهاى مركزى ايران نيز جنــان رضـايت بخـش نيست

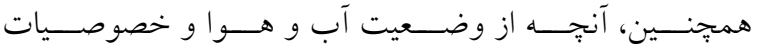
خشكسالىها در استان سمنان نيز استنباط مسى خـردد ايـن كونـه

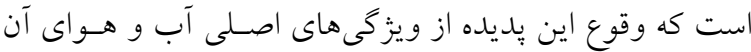
مى باشد. يُزوهش حاضر، تلاشى است تـا بـا استفاده از آمـار و

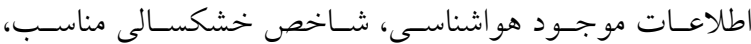
مدلها و الكوهاى خطى و غيرخطى سرىهاى زمانى، شبكههاى

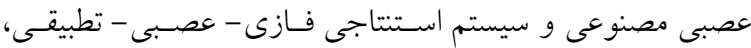
مدل مناسبى براى بيشبينى خشكسالى شهر سـمنان در مقيـاس زمانى كو تاه مدت ماهانه ارائه كردد.

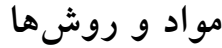
منطقه مورد مطالعه و پِارامترهاى مورد استفاده

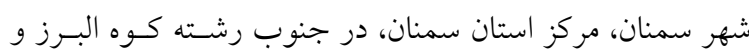

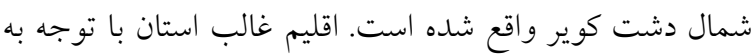
محاسبات دو روش طبقهبندى اقليم كوين و دومـارتن، بـه جــز

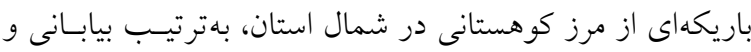

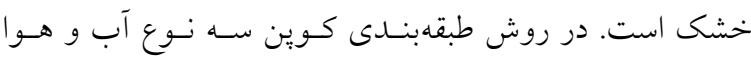

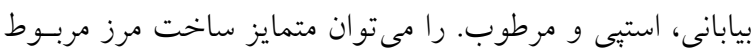

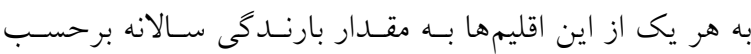

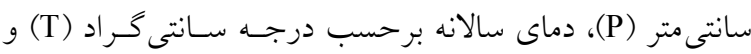

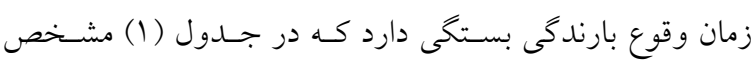
شده است.

هم:حنين دومارتن جهت طبقهبندى اقليم بـين دمـا و مقــدار بارندكى رابطه تجربى (1) را ييدا كرد: $I=\frac{P}{(T+10)}$ 
نشر يه علوم آب و خاك (علوم و فنون كثاورزى و منابع طبيعى) / سال بيست و يك / شماره جهار / زمستان وهج|

\begin{tabular}{|c|c|}
\hline \multicolumn{2}{|c|}{ جدول r. تقسيمبندى ارزيابى شاخص بارش استاندارد } \\
\hline شاخص SPI & وضعيت خشكسالى \\
\hline$-r$ & خشكسالى بسيار شديد \\
\hline -1/0 إ - 1/99 & خشكسالى شديد \\
\hline$-1 \mid-1 / 4 q$ & خشكسالى متوسط \\
\hline 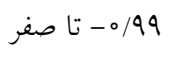 & 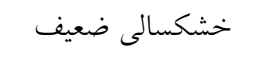 \\
\hline صفر & 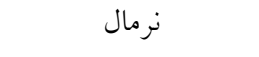 \\
\hline صفر تا 99/ه & ترسالى ضعيف \\
\hline ا تا 1/49 & ترسالى متوسط \\
\hline 1/99 1/0 تا 1/0 & ترسالى شديد \\
\hline r & ترسالى بسيار شديد \\
\hline
\end{tabular}

مى گردد كه همان مقدار SPI است. طبقهبندى ارزيابى شـاخص SPI

\section{سرىهاى زمانى}

از جمله مدلهاى آمارى يركاربرد سرىهاى زمانى مىباشند كـه

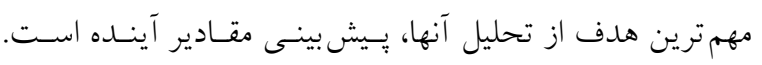

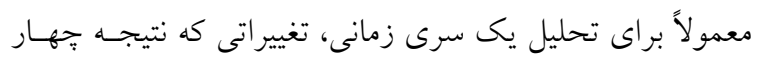
مؤلفــه رونسـ، تغييـرات فصـلى، دورهاى و نـامنظم (تصـادفى)

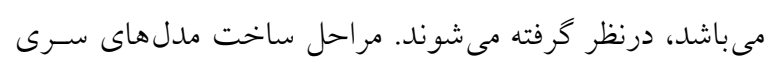

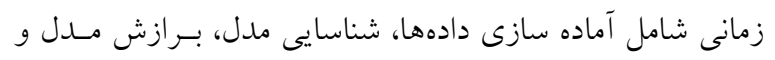
تشخيص اعتبار مدل مىباشد (9). مراحل فوق با اسـتفاده از دو نرمافزار EVinitab16 و انجام شده است. تعيسين فـرم

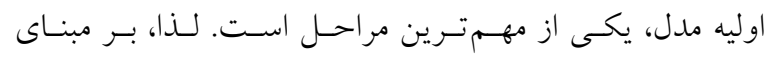
تحقيقات كذشته، مدل سازى در خانواده آرما، آريمـا و آريمـاى

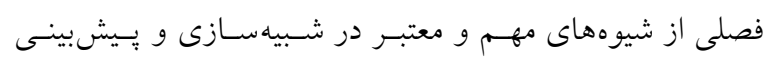
يارامترهاى اقليمى مىباشند كه علاوه بر توليد، قابليت بيشبينى

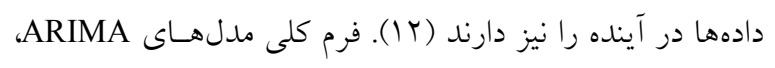
كه قابليت مدلسازى برخى از سـرىهـاى زمـانى نايسـتا را بـا تفاضلى كردن سرى مـورد نظـر دارنـــ بـهـصورت معادلـه (r)

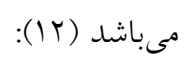
$\varphi(\mathrm{B}) \nabla^{\mathrm{d}} \mathrm{X}_{\mathrm{t}}=\theta(\mathrm{B}) \mathrm{Z}_{\mathrm{t}}$
شاخص خشكسـالى منتخــب در ايـن يـرّزوهش (SPI) در سال سوا توسط مك كـى و همكـاران ارائسه شـد (IV). ايسن

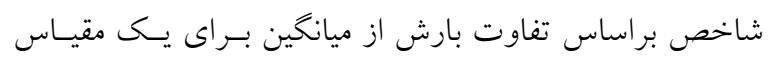

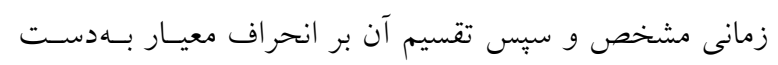

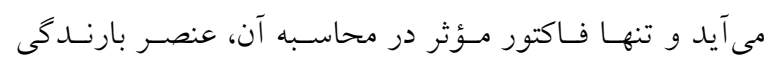
مىباشد. اين شاخص را مىتوان در مقياسهـاى زمـانى كوتـاه مدت و بلند مدت محاسبه كـرد. شـاخص SPI از معادلـه (Y)

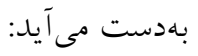

S P I $=\frac{P_{i}-\bar{P}}{S}$

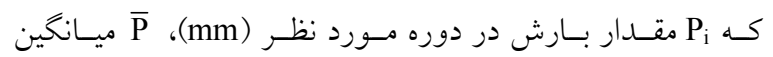
درازمدت بارش براى دوره مورد نظر و S انحراف معيـار مقــدار

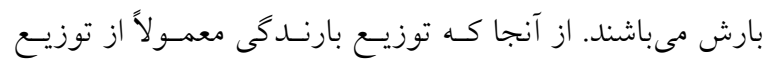

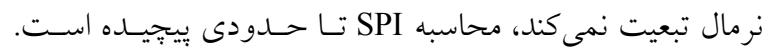
براى محاسبه اين شاخص، ابتــا از يـك توزيـع مناسـب مانـــــ توزيع كاما يا بيرسون تيڤٍ سه براى برازش دادههـاى بلندمـدت بارش استفاده مىشود (Y). سبّ، محاسبه و تعيسين بِارامترهـاى مربوط به SPI انجام مى گيرد. محاسبه SPI شـامل بـرازش تـابع جخالى احتمال گاما بر توزيع فراوانى بارندكى مى باشد و جــون تابع گاما براى مقادير صفر بارش تعريف نشده است از احتمـال

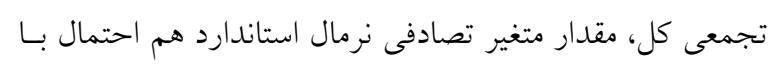

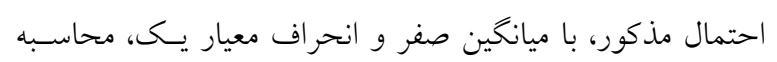


هيبربوليك مىباشند كه در اين تحقيق در مـدلهـاى سـاخته

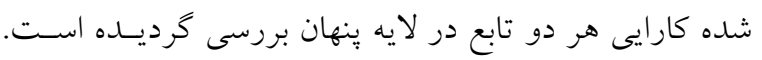

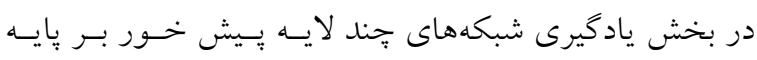

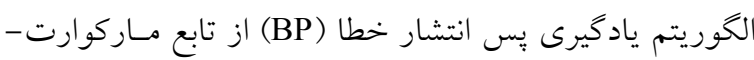

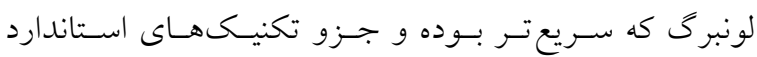

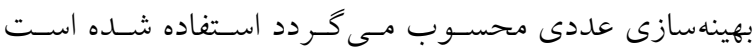

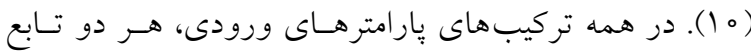

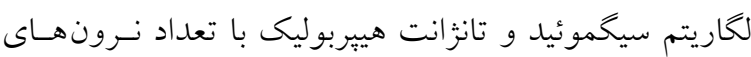

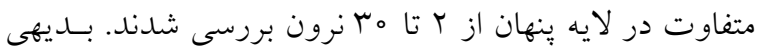

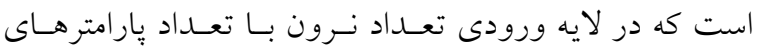

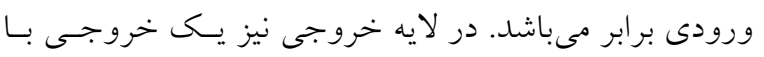

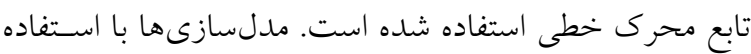

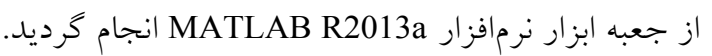

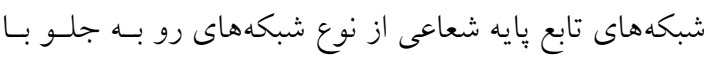

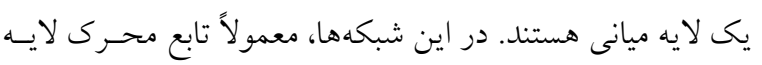
ميانى، تابع كوسى و در لايه خروجى تابع خطى مسياشـــــ (19).

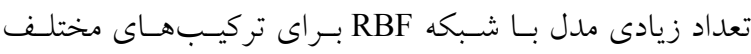
ورودى و ثابتهاى كسترش متفـاوت بـا كدنويسى در محسيط

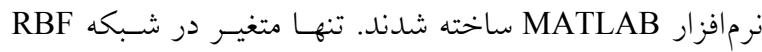

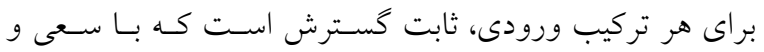

$$
\text { خطا، مقدار بهينه آن تعيين مى كردد. }
$$

در مدلسازىها با هر دو شبكه مذكور، ابتدا استانداردسازى

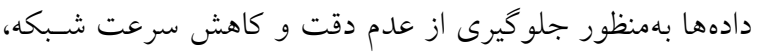

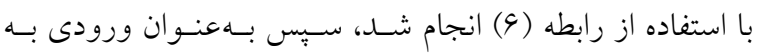

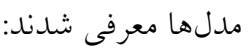

$$
X_{n}=\circ / 00+\circ / 90\left(\frac{x-x_{\text {min }}}{x_{\text {max }}-x_{\text {min }}}\right)
$$

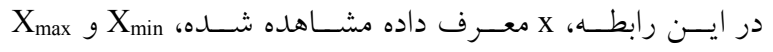

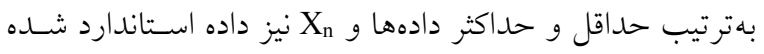

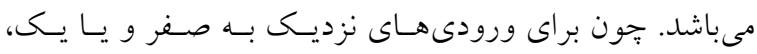

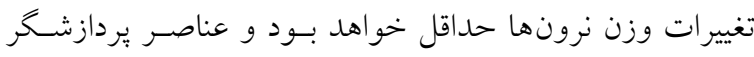

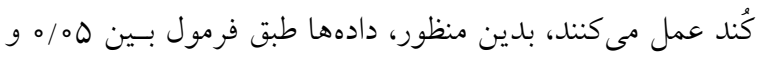

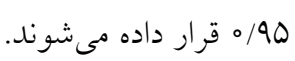

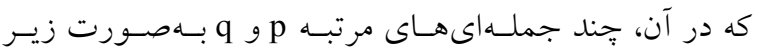

$\varphi(B)=1-\varphi_{1} B-\varphi_{r} B^{r}-\cdots-\varphi_{p} B^{p}$

$\theta(B)=1-\theta_{\uparrow} B-\theta_{r} B^{r}-\cdots-\theta_{q} B^{q}$

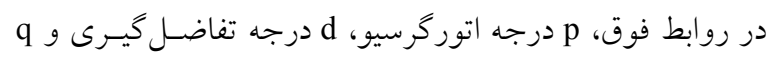

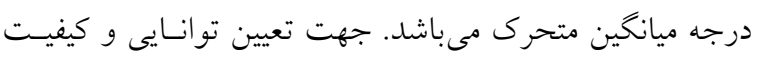

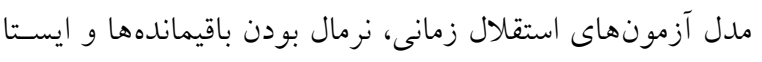

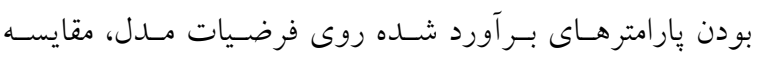

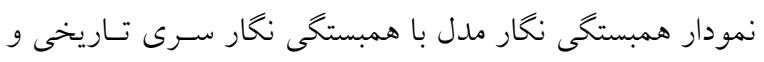

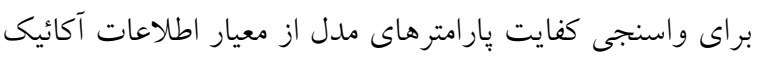

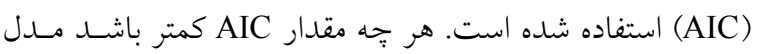
عملكرد مناسبترى دارد (r و 9).

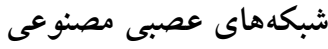

شبكه هاى عصبى مصسنوعى (ANN) يـك سيسـتم هـردازش اطلاعات است كه براساس شبيهسازى عملكرد مغز انسان بنـا

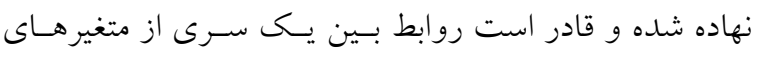

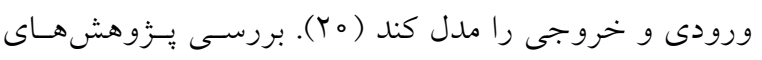

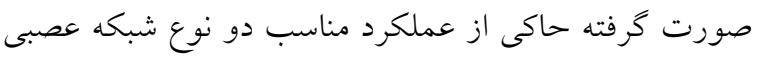

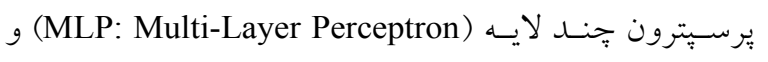

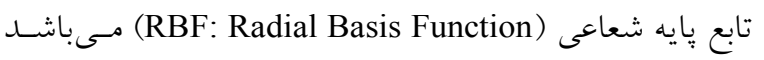

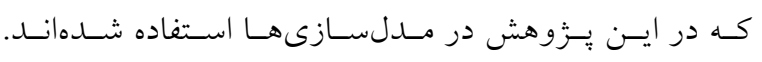

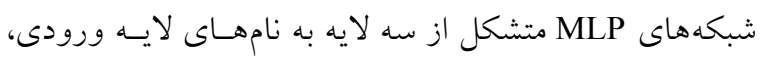

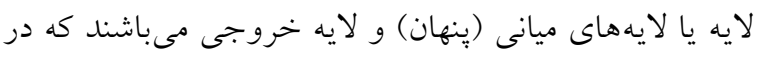

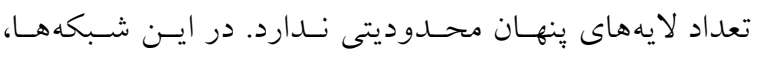

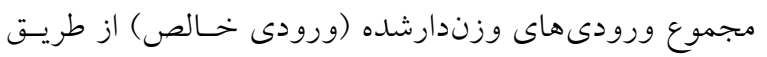
يك تابع محرك به مقدار خروجى تبديل مسى شـودود. در لايسه

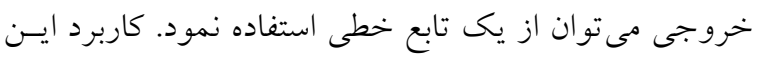

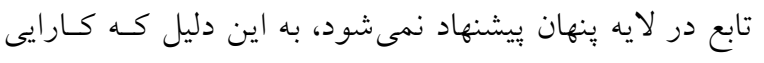

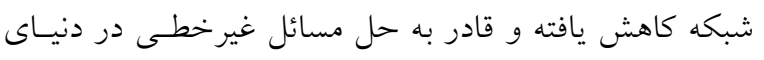

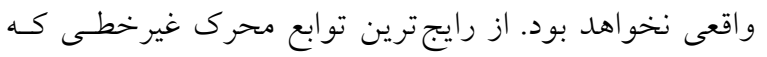

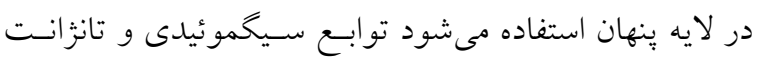



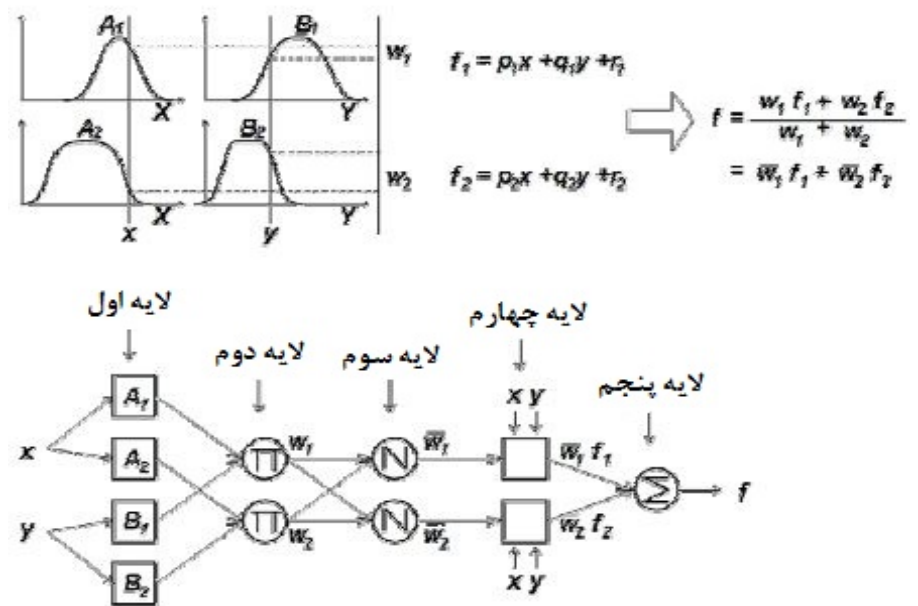

ANFIS شكل ا. نمونهاى از ساختار

مدلسازىهاى سيستمهاى استتناج فازى- عصبى تطبيقى بـا

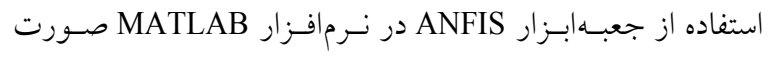

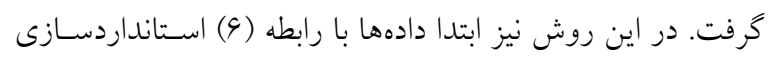

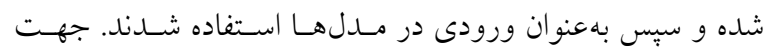

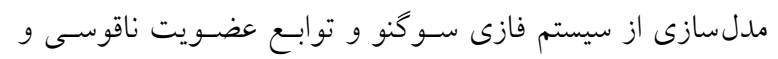

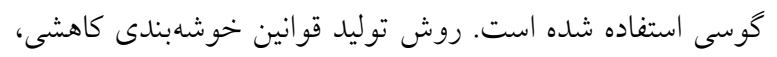

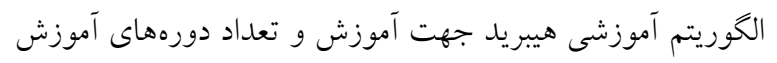

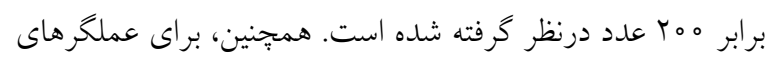

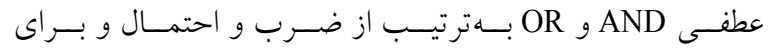
غيرفازىسازى نيز از غيرفازىساز متوسط وزندار استفاده كرديد.

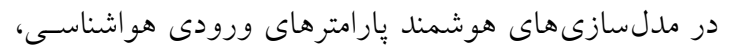

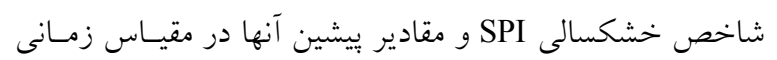

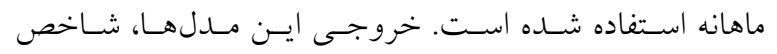

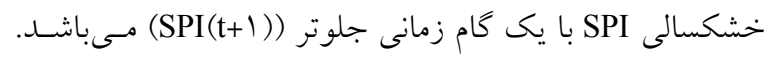
در مدلهاى سرى زمانى، شـاخص خشكسـالى SPI در مقيـاس

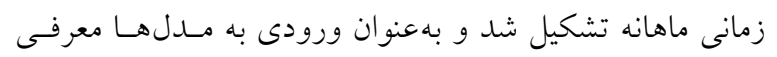

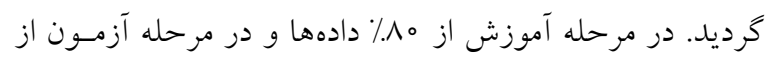

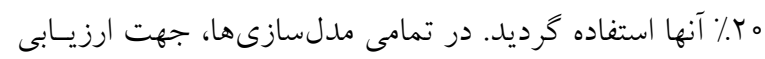

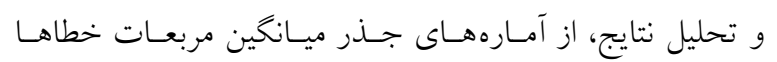

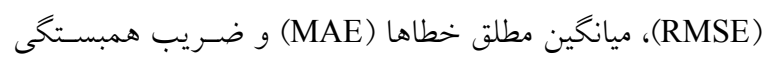

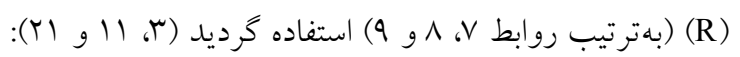

سيستمهاى فازى بر پايه شبكه عصبى تطبيقى (ANFIS)

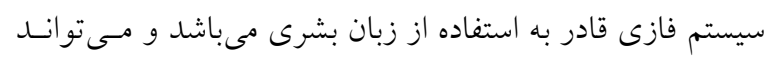

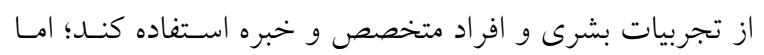

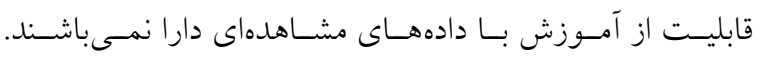

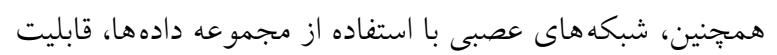

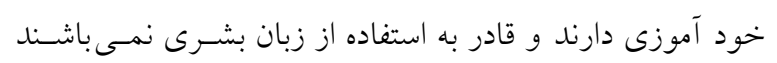

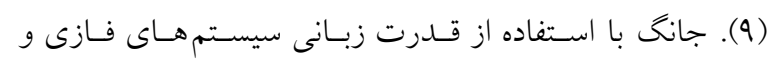

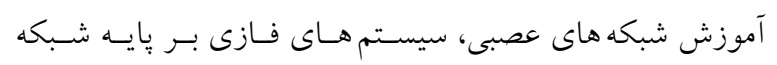

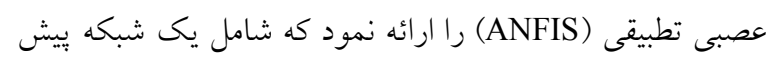

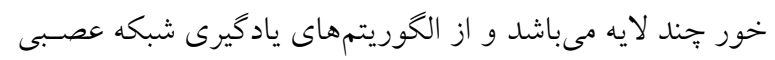

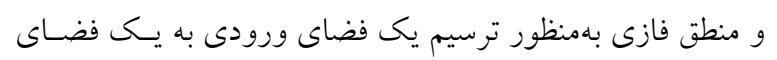

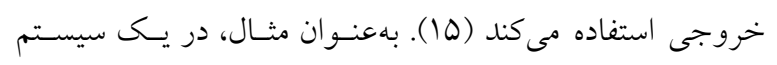

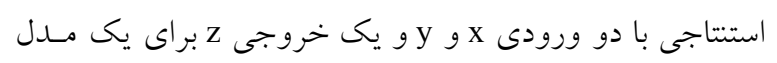

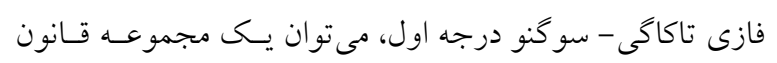

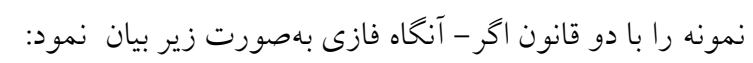
$z_{1}=p_{1} x_{1}+q_{1} y_{1}+r_{1}$ :بردان

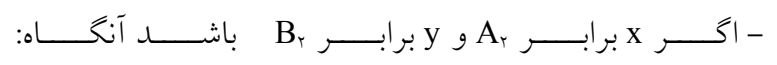

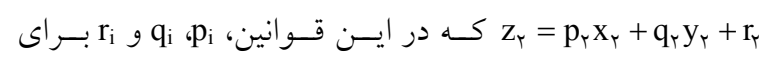

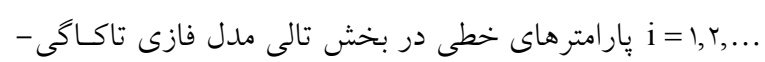

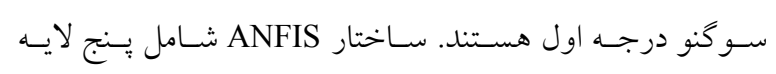

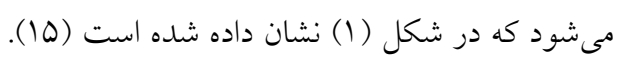




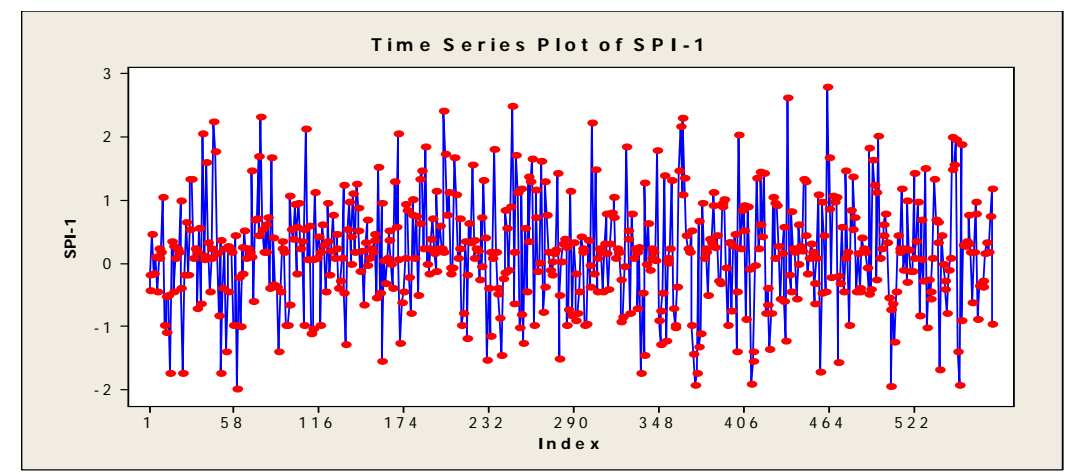

شكل r. نمودار سرى زمانى شاخص خشكسالى SPI در مقياس زمانى ماهانه

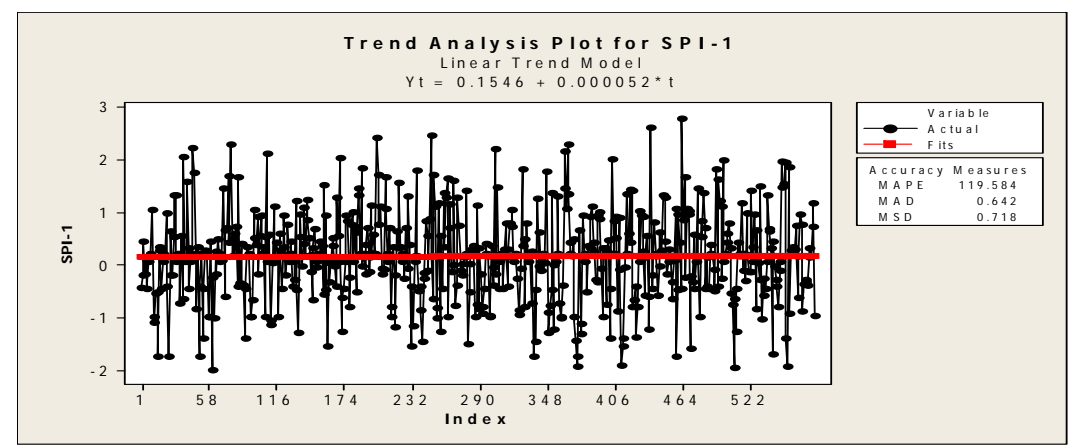

شكل r. بررسى روند سرى زمانى شاخص خشكسالى SPI در مقياس زمانى ماهانه

مدلسازى در نرمافزار Minitab انجام شده اسـت. ابتــا سـرى مورد نظر رسم كرديد، كه در شكل (Y) نمـودار آن آورده شــده

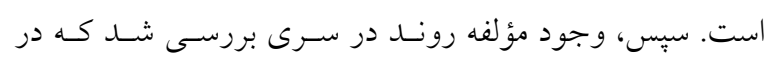

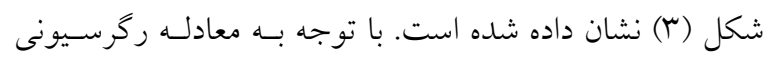

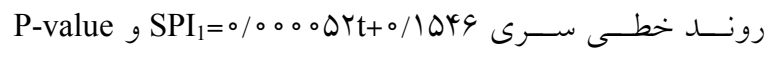

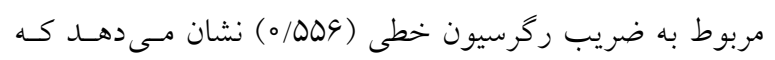
شيب اين خط ركرسيونى در سطح هـ معنى دار نمىباشـد. لـذا،

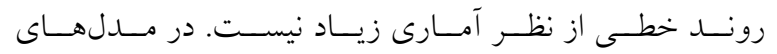
ARIMA(p,d,q) ايستايى سرى، يـارامتر d از مرتبـه صـفر درنظـر كرفتـه شـدند.

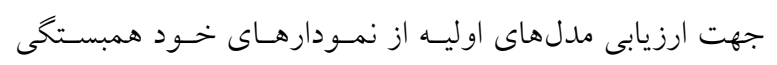
و خود همبستخى جزئى (ACF)

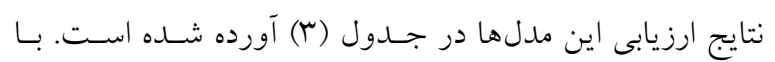

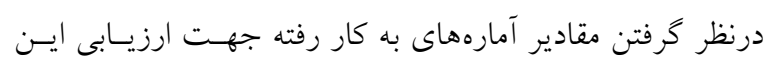

$$
\operatorname{RMSE}=\sqrt{\frac{1}{n} \sum_{i=1}^{n}\left(x_{i}^{o}-x_{i}^{p}\right)^{r}}
$$

$$
\mathrm{MAE}=\frac{1}{\mathrm{n}}\left|\left(\mathrm{x}_{\mathrm{i}}^{\mathrm{o}}-\mathrm{x}_{\mathrm{i}}^{\mathrm{p}}\right)\right|
$$

$R=\frac{\sum_{i=1}^{n}\left(x_{i}^{o}-\bar{x}^{o}\right)\left(x_{i}^{p}-\bar{x}^{p}\right)}{\sqrt{\sum_{i=1}^{n}\left(x_{i}^{o}-\bar{x}^{o}\right)^{r} \sum_{i=1}^{n}\left(x_{i}^{p}-\bar{x}^{p}\right)^{r}}}$

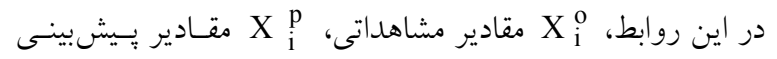
شده، X بيش بينى شده مى باشند. هر جهه مقادير RMSE و

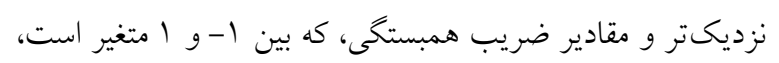
به مقدار ا نزديكتر باشد نشان دهنده عملكرد بهتر مدل است. نتايج و بحث به منظور مدلسازى سرىهاى زمانى، يس از تأييد ايستايى سرى ماهانــ SPI بــا اسـتفاده از نــرم|فـزار EViews، ادامــه مراحـل 


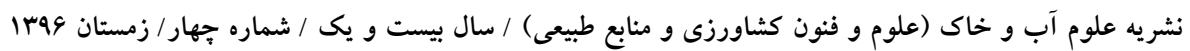

جدول r. ارزيابى نتايج بيشبينى خشكسالى با مدل سرى زمانى ARIMA

\begin{tabular}{|c|c|c|c|c|c|c|c|}
\hline \multicolumn{3}{|c|}{ آزمون } & \multicolumn{4}{|c|}{ آموزش } & \multirow{2}{*}{ فرم مدل } \\
\hline Corr. & MAE & RMSE & AIC & Corr. & MAE & RMSE & \\
\hline$\circ / \circ \Delta r$ & $0 / 94$ & o/AVY & $-191 / V$ & $0 /|\psi|$ & $0 / 9 M Y$ & o/AY & $\operatorname{ARIMA}\left(1,0^{\circ},{ }^{\circ}\right)$ \\
\hline$\circ / \circ V Y^{C}$ &.$/ 901$ & $\circ / \wedge \mathrm{V}$ & $-190 / 0$ & $0 / N F$ & o/Ard & 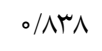 & $\operatorname{ARIMA}(1, \circ, 1)$ \\
\hline $0 / T_{1}$ & $0 / 94$ & $\circ / \wedge \Delta$ & $-10 / / 0$ & $0 / I F V$ & -/ATd & $\circ / \Lambda Y$ & $\operatorname{ARIMA}(1,0, r)$ \\
\hline.$\% 9 V \pi$ &.$/ 90$ & - /Nৎ9 & $-10 / / 0$ &.$/ I F$ & ס Dra & o/Arq & $\operatorname{ARIMA}(Y, \circ, 1)$ \\
\hline O/TY & $0 / 949$ & $\circ / \Lambda \Delta 1$ & $-104 / 0$ &.$/ T Y V$ & o/grd & o/Arq & $\operatorname{ARIMA}(r, \circ, r)$ \\
\hline O/TKF & - /9QR & - /A99 & $-10 V / 1$ &.$/ 101$ & $0 / 949$ & -/Аイی & $\operatorname{ARIMA}(r, \circ, 1)$ \\
\hline$\circ / T \circ r$ & $0 / 949$ & -/NDY & $-|V| / 4$ & $0 / T M V$ & O/GMT & ס/AYr & ARIMA $(r, \circ, r)$ \\
\hline $0 / 119$ & $0 / 94 V$ & $\circ / \Lambda \Delta V$ & $-109 / V$ & $\circ / I V A$ & O/GMA & •/Ard & ARIMA $(r, \circ, r)$ \\
\hline ./1 & $0 / 909$ & $\circ / \wedge \& D$ & $-100 / 1$ & $0 /|0|$ & ./949 & 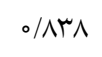 & 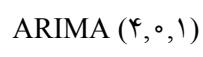 \\
\hline
\end{tabular}

\begin{tabular}{|c|c|c|c|}
\hline P-value & ضريب & مرتبه & نوع \\
\hline $0 / 000$ & $\circ / Q \wedge Y \mid$ & 1 & AR \\
\hline $0 / 000$ & $-0 / 9 V V Y$ & r & AR \\
\hline O/OOY & - MYAY & $r$ & AR \\
\hline $0 / 000$ & $0 /$ YYDI & 1 & MA \\
\hline $0 / 000$ & $-0 / 9 \wedge \Delta \psi$ & r & MA \\
\hline$\circ / 0 \circ \circ$ & $\circ / T \circ 9 V 1$ & - & تابت \\
\hline
\end{tabular}

\begin{tabular}{|c|c|c|c|c|}
\hline \multicolumn{5}{|c|}{ آزمون Ljung-Box } \\
\hline$\uparrow \wedge$ & re & YY & IT & تأخير \\
\hline $0 / 4 \wedge$ 。 & $0 / T ৭ \Delta$ & - / QG & $\circ / \pi \Delta q$ & P-value \\
\hline
\end{tabular}

ضرايب مدل برتر و همجنين P-value آمـاره خطـاى اسـتاندارد هر ضريب (t) نشان داد كه تمامى ضرايب در سطح ه.\% معنىدار مسىباشـند، كه مقـادير آنهـا در جــدول (t) آورده شــده اسـت. همجنين P-value آماره آزمـون Ljung-Box نيـز در تأخيرهـاى مختلف، كه بزرگتر از سطح معنسى دارى ه.٪ مسىباشـند فـرض صفر، كه فـرض ناهمبسـته بـودن باقيمانـدههـا اسـت، را تأييــ مى كند. اين مقادير در جدول (ه) نشان داده شده است.
مدل ها و همجنين مقايسه نمودارهـاى ACF و PACF مــل بـا نمسودارهـاى ACF و PACF سـرى تـاريخى، درنهايست مــل ARIMA(Y،。، به (r)

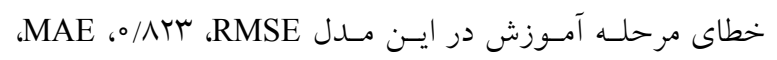

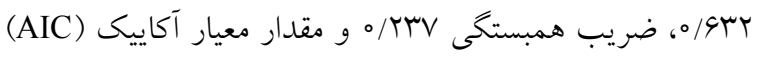

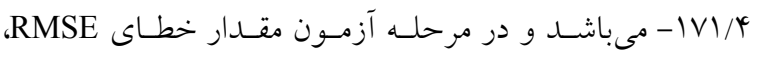
(MAE ،/ADY 


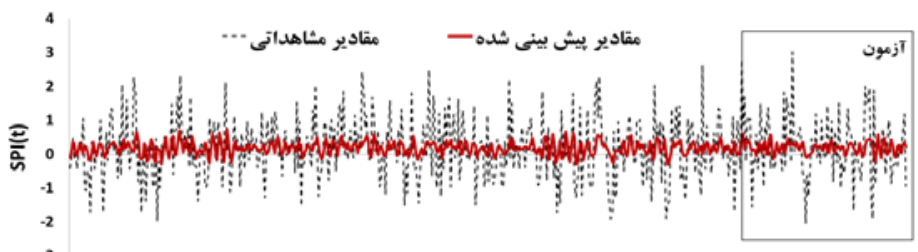

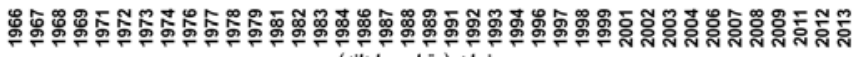

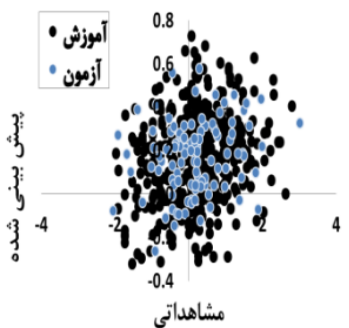

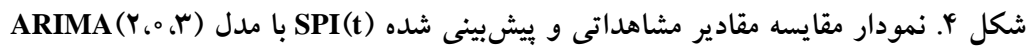

جدول و. ارزيابى نتايج بيشبينى خشكسالى با شبكه عصبى MLP

\begin{tabular}{|c|c|c|c|c|c|c|c|c|c|}
\hline \multicolumn{3}{|c|}{ آزمون } & \multicolumn{3}{|c|}{ آموزش } & \multirow{2}{*}{ تعداد نورون } & \multirow{2}{*}{ لايه خروجى محرى } & \multirow{2}{*}{ لابع محرك } & \multirow{2}{*}{ يار امتر (هاى) ورودىى } \\
\hline Corr. & MAE & RMSE & Corr. & MAE & RMSE & & & & \\
\hline $0 / T Y$ &.$/ 940$ & o/Art & $0 / 794$ & $0 / 9 T$ & $\circ / \Lambda \mid \wedge$ & 4 & Purelin & logsig & $\operatorname{SPI}\left(t, t-1, t-r, t-r, t-r^{\leftarrow}\right)$ \\
\hline D & $0 / 949$ & $\circ / \Lambda \Delta Y^{F}$ & $\circ / T$ & س & ( & ir & Purelin & Tansig & $P(t, t-1)$ \\
\hline$\circ / T V$ & ./940 & $\circ / 1 / 0$ & . TV & $0 / 94$ & $\circ / \Lambda I V$ & ro & Purelin & logsig & $\operatorname{Tmax}(t, t-1)$ \\
\hline$\circ / \backslash \wedge \Lambda$ &.$/ 901$ & o/NHY & $\circ / T \circ V$ & $0 / 94$ & 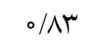 & ir & Purelin & Tansig & $\mathrm{RH}(\mathrm{t}, \mathrm{t}-\mathrm{l}, \mathrm{t}-\mathrm{r})$ \\
\hline$\circ / T V G$ & olgkt & $0 / 119$ & $0 / Y_{q}$ & $0 / 94$ & $\circ / \Lambda 1$ & ro & Purelin & Tansig & $\operatorname{SPI}(\mathrm{t}), \operatorname{Tmax}(\mathrm{t})$ \\
\hline ( &.$/ 90 \mathrm{~V}$ & 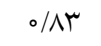 & O/TAY & $0 / 94$ & $\circ / \mathrm{N} \mathrm{V}$ & 11 & Purelin & Tansig & $\mathrm{SPI}(\mathrm{t}), \mathrm{P}(\mathrm{t}), \operatorname{Tmax}(\mathrm{t})$ \\
\hline
\end{tabular}

همبسـتكى MA همبستكى TV9/ در مرحله آزمون، با عملكـرد مناسـب نسـبت

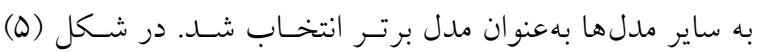

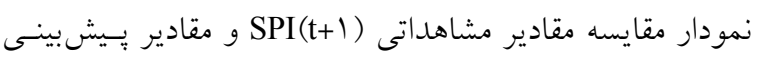
شده با استفاده از مدل مذكور آورده شده است. در مدلسازى روش شبكه عصبى RBF، با توجه بــه حجـم بالاى مدلها، براى تركيبهاى مختلف ورودى فقط برخى نتايج

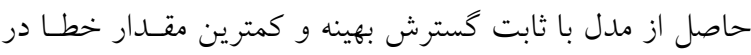

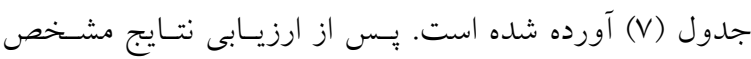
كرديد كه اين نوع از شبكههاى عصبى عملكرد ضـعيفتـرى را نسبت به شبكه عصبى MLP در مدلسازى از خود نشان داد. از

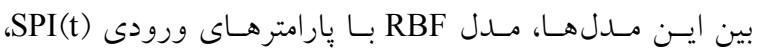

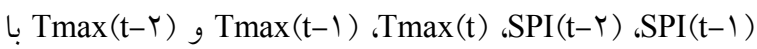

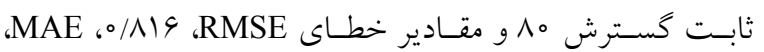

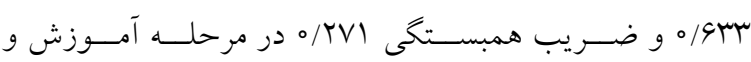
RMSE

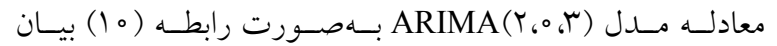

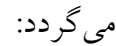
$X_{t}=\circ / \Delta \wedge r \mid\left(X_{t-1}\right)-。 / q V V \psi r\left(X_{t-r}\right)+\circ / / \mu \wedge r\left(X_{t-r}\right)$ $+\circ /$ r०qVI+०/ YYOLI $\left(\varepsilon_{\mathrm{t}-1}\right)-\circ / 9 \wedge \Delta Y\left(\varepsilon_{\mathrm{t}-\mathrm{r}}\right)$ در شـكل (t)، نمــودار مقــادير مشــاهداتى (SPI(t) و مقــادير بيشبينى شده با استفاده از مدل مذكور آورده شده است. در مدلسازىهاى شبكه عصبى MLP، بـا توجـه بـه حجـم بالاى مدلها، فقط نتايج برتر برخى از تركيـبهـاى ورودى در

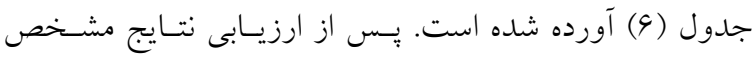
كرديد كه يارامترهاى شاخص خشكسالى SPI، ميـانخين دمـا و ميانخين حداكثر دما عملكرد بهترى را نسبت به سـاير بارامترهـا دارا بودند و ويار امتر ميانخين بارش ضـعيفتـــين عملكـــد را از خود نشان داد. درنهايت، با بررسى مقادير خطاى تمامى مدلها،

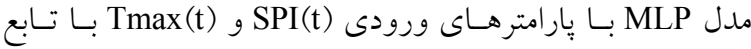
محرك تانزانت هيبربوليك و ها نرون در لايسه يُنهـان و مقـادير

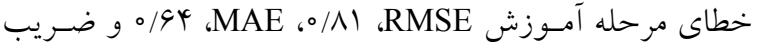




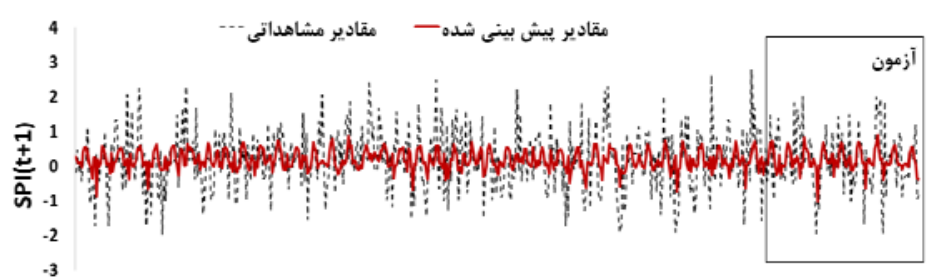

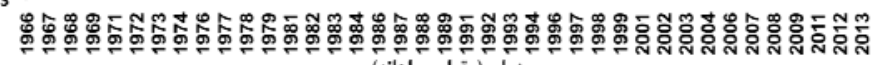
زمان (مقياس ماهانه)

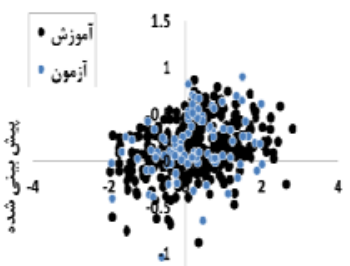

$-1.5$ مشانداتي

شكل ه. نمودار مقايسه مقادير مشاهداتى و ييشبينى شده ( SPI(t+1 با مدل MLP با دو ورودى (t) و

تابع تانزانت هيبربوليك و M Y نورون در لايه ينهان

جدول V. ارزيابى نتايج يشيشى خشكسالى با شبكه عصبى RBF

\begin{tabular}{|c|c|c|c|c|c|c|c|}
\hline \multicolumn{3}{|c|}{ 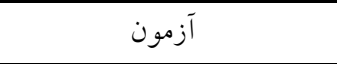 } & \multicolumn{3}{|c|}{ 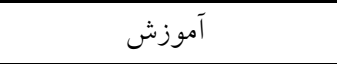 } & \multirow{2}{*}{ ثابت كسترش } & \multirow{2}{*}{ پار امتر (هاى) ورودى } \\
\hline Corr. & MAE & RMSE & Corr. & MAE & RMSE & & \\
\hline -/109 & ०/AM & $0 / N F \mid$ & O/TYG & O/GTV & o/ATG & 100 & 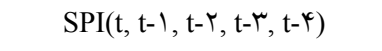 \\
\hline$\circ / 1 \circ \varphi^{c}$ & $0 / 940$ & o/AFY & $\circ / T V$ & O/GMt & $\circ / \Lambda F \mid$ & 100 & $p(t, t-1)$ \\
\hline $0 / 149$ & o/9kr & •/Arv & $0 / 119$ & $0 / 94$ & o/NAt & 100 & $\operatorname{Tmax}(t, t-1, t-r)$ \\
\hline $0 / 149$ & $0 / 991$ & $\circ / \Lambda \mu_{q}$ & $\circ / r$ & $0 / 949$ & ०/AMI & 100 & $\mathrm{RHmin}(\mathrm{t}, \mathrm{t}-1)$ \\
\hline O/YYY & $\circ / 9 \mu \wedge$ & $\circ / \Lambda T_{1}$ & $\circ / Y V I$ & olapr &.$/ 199$ & $\wedge \circ$ & $\operatorname{SPI}(\mathrm{t}, \mathrm{t}-\mathrm{l}, \mathrm{t}-\mathrm{r}), \operatorname{Tm} \max (\mathrm{t}, \mathrm{t}-\mathrm{l}, \mathrm{t}-\mathrm{r})$ \\
\hline O/TKY & $0 / 944$ & $\circ / \Lambda r \mid$ & $0 / T \& V$ & O/GMt & o/NIV & $9 \circ$ & $\mathrm{SPI}(\mathrm{t}), \mathrm{P}(\mathrm{t}), \mathrm{T}(\mathrm{t}), \mathrm{RH}(\mathrm{t})$ \\
\hline
\end{tabular}

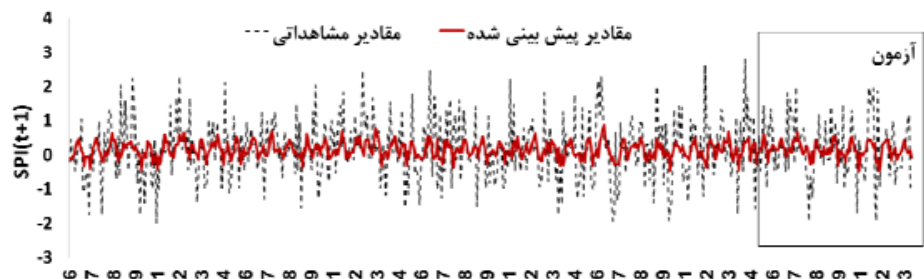

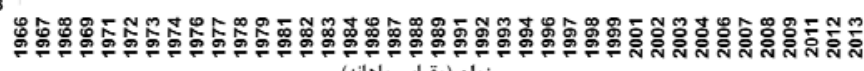

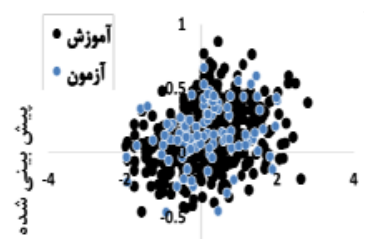

مشاهداتى

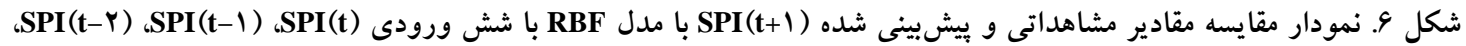
ᄉ. $\operatorname{Tmax}(t-Y) ، \operatorname{Tmax}(t-1) ، \operatorname{Tmax}(t)$

يارامترهاى شاخص خشكسـالى SPI، ميـانگين دمـا و ميـانگين حداكثر دما عملكرد بهترى را نسبت به ساير يارامترها دارا بودند و يارامتر ميانخين بارش عملكرد ضـعيفى را از خــود نشـان داد.

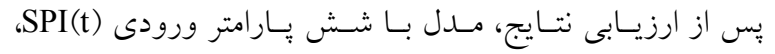

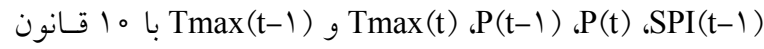

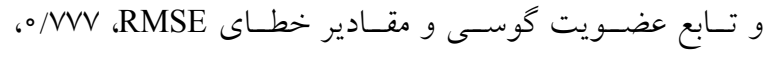
MAE
مرحله آزمون، بهعنوان مــل برتــــ انتخـاب شــــ در شـكل (9) نمودار مقايسه مقادير مشاهداتى (SPI(t+1 و مقادير يسيشبينى شده با استفاده از اين مدل آورده شده است. در مدلسازى با استفاده از روش ANFIS، با توجه به حجم بالاى مدلها، براى تركيبهـاى مختلـف ورودى، فقـط برخسى نتايج مدلها با تعداد قوانين بهينه و كمترين خطا در جدول (^) آورده شده است. يـس از ارزيـابى نتـايج مشـخص كرديـــ كـه 
انتخاب مدل مناسب براى بيشبينى خشكسالى شهر سمنان در مقياس زمانى كوتاه

جدول ^ ارزيابى نتايج بيشبينى خشكسالى با سيستم استنتاج فازى- عصبى تطبيقى ANFIS

\begin{tabular}{|c|c|c|c|c|c|c|c|c|c|}
\hline \multicolumn{3}{|c|}{ 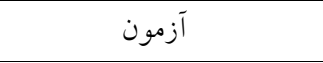 } & \multicolumn{3}{|c|}{ 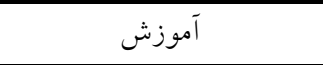 } & \multirow{2}{*}{ قع انين } & \multirow{2}{*}{ تابع عضويت } & \multirow{2}{*}{ عضابع } & \multirow{2}{*}{ پيار امتر (هاى) ورودى } \\
\hline Corr. & MAE & RMSE & Corr. & MAE & RMSE & & & & \\
\hline$\circ / I V T$ &.$/ 90 \mathrm{~V}$ & o/ATG & $\circ / \mu v$ & $0 / 9 \circ 9$ & $\circ / V \wedge V$ & r & Linear & gaussmf & $\operatorname{SPI}\left(\mathrm{t}, \mathrm{t}-\mathbf{l}, \mathrm{t}-\mathrm{r}, \mathrm{t}-\mathrm{r}, \mathrm{t}-\mathrm{r}^{\mathrm{r}}\right)$ \\
\hline$\circ \diamond \wedge$ & .1994 & -/AQT & O/TYG & ./GTV & o/ATG & 4 & Linear & gaussmf & $P(t, t-1, t-r)$ \\
\hline o/TMY &.$/ 949$ & O/ATV & o/rit & O/GYA & $\circ / 1 \circ 9$ & 4 & Linear & gbellmf & $\mathrm{T}(\mathrm{t})$ \\
\hline$\circ / \curlywedge \wedge \vee$ & olaYt & ०/Ar & $\circ / \backslash \wedge \Delta$ & $0 / 949$ & 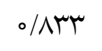 & $\Delta$ & Linear & gaussmf & $\mathrm{RHmin}(\mathrm{t}, \mathrm{t}-\mathrm{l})$ \\
\hline $0 / \pi / 9$ & $0 / 990$ & $\circ / 119$ & $\circ / 401$ & $0 / 9$ & $\circ / \mathrm{V} \wedge$ & r & Linear & gbellmf & $\operatorname{SPI}(\mathrm{t}, \mathrm{t}-\mathrm{l}, \mathrm{t}-\mathrm{r}), \mathrm{RH} \min (\mathrm{t}, \mathrm{t}-\mathrm{l}, \mathrm{t}-\mathrm{r})$ \\
\hline OMGY & $0 / 944$ & $\circ / \Lambda M V$ & $\circ / 4$ & ./094 & $\circ / \mathrm{VV}$ & 10 & Linear & gaussmf & $\operatorname{SPI}(t, t-1), P(t, t-1), \operatorname{Tmax}(t-1)$ \\
\hline
\end{tabular}

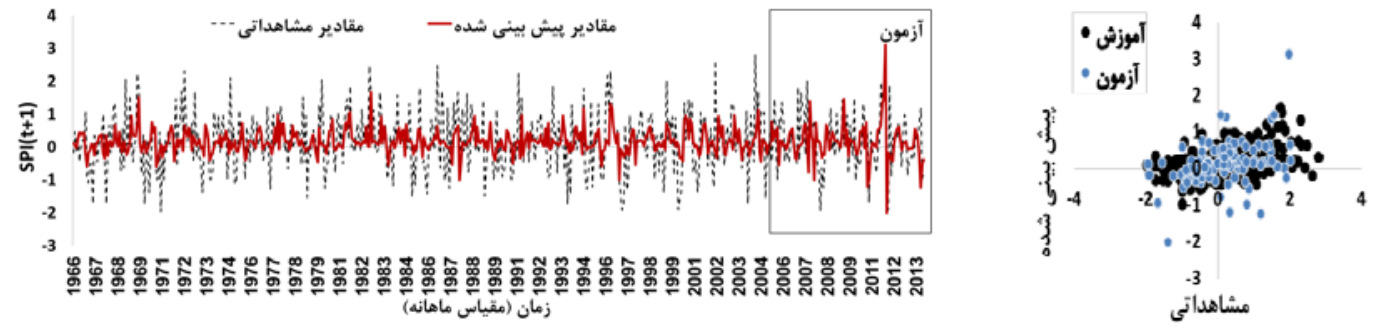

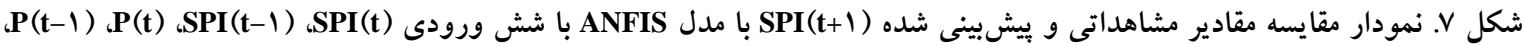
Tmax(t-1)، Tmax(t)

كوسى و ه $ا$ قانون بهعنوان مدل برتر انتخاب كرديد.

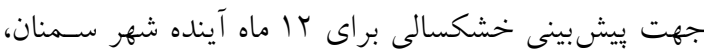

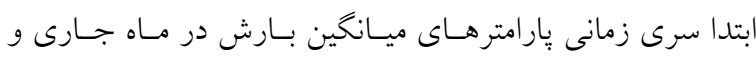

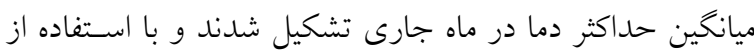

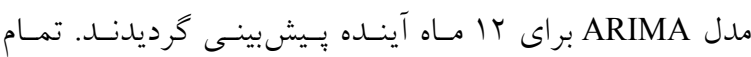

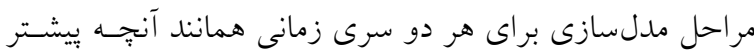

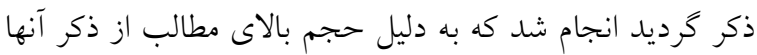
خوددارى شده است. پِس از مدلسازىها و بررسى نتايج ، مدل

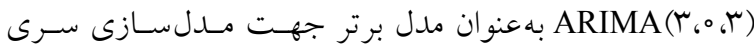

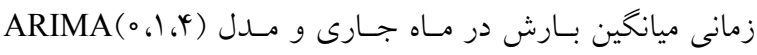
بهعنو ان مدل برتر جهت مدلسازى سرى زمانى ميانخين حداكثر

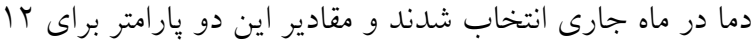

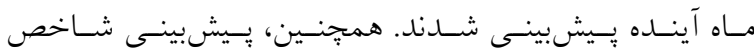

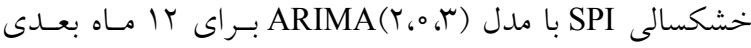

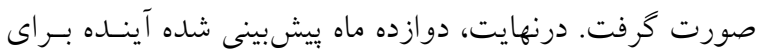

ماله

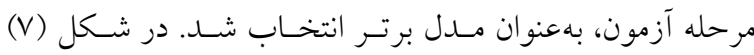

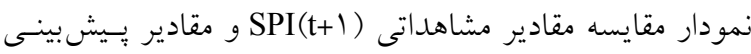

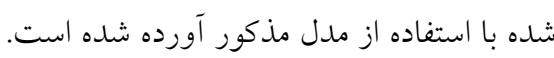

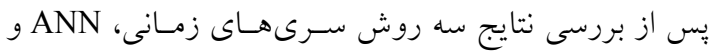

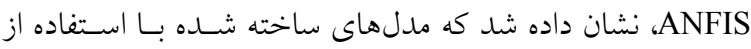

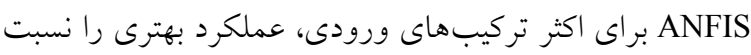

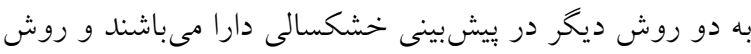

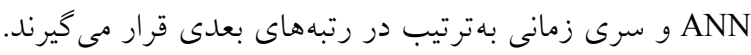

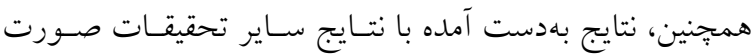

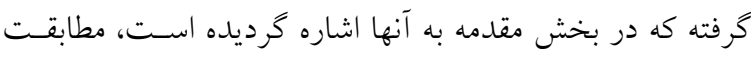

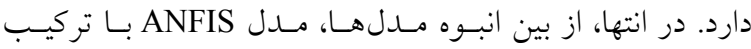
يارامترهاى ورودى شـاخص خشكس نشالى SPI در مـاه جـارى و يك ماه قبل، ميانگين بارش در مـاه جــارى و و يـك مـاه قبـل، و و

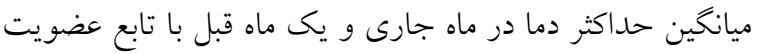




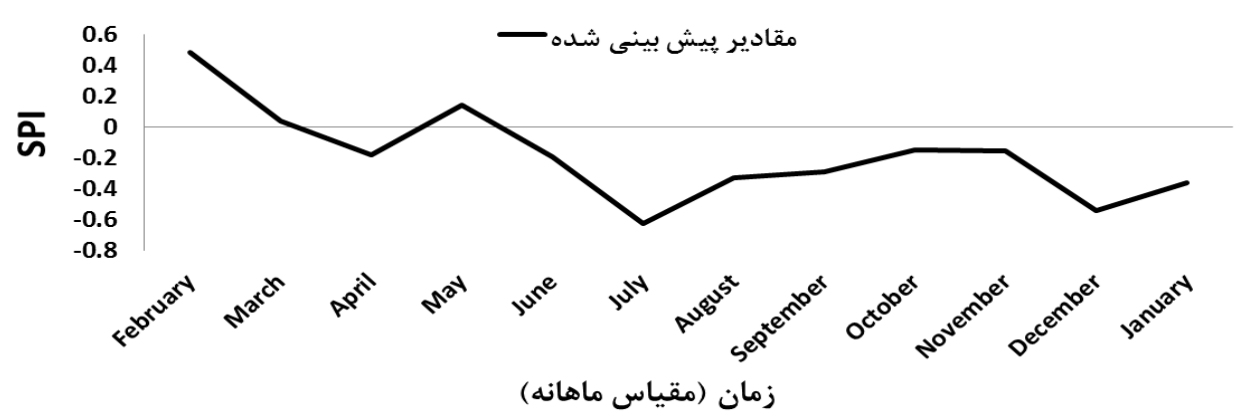

شكل ^م نمودار مقادير بيشبينى شده شاخص خشكسالى SPI براى دوازده ماه آينده با شش ورودى (t) SPI(t)، SPI(t-1)،

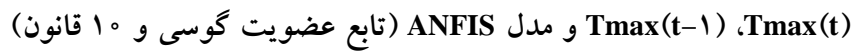

انتظار داشـتيم، روش ANFIS ارجــحتـر تشـخيص داده شـد و روش هاى شبكه عصبى مصنوعى و سرى زمـانى در رتبـهـهـاى

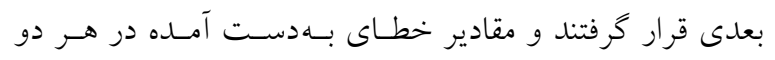
مرحله آموزش و آزمون در مدلهاى برتر تا حدود زيادى مشابه

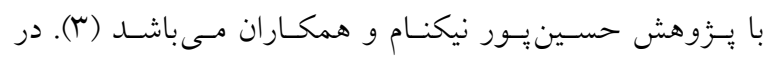

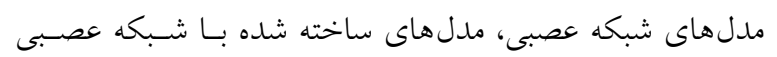

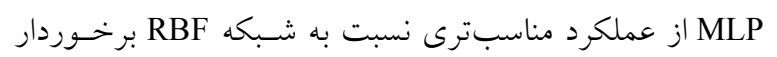
بودند. همجينين، در تركيبهاى مختلـف ورودى تـابع محـرك،

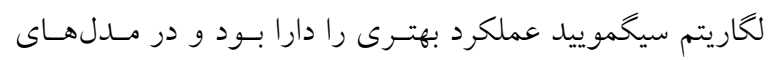

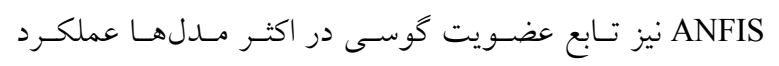
مناسبى را نشان داد. اما، اين توابع بهطور قطع تابع محرى برتـر تشـخيص داده نشــنلد. از بـين يارامترهــاى ورودى، شـاخص

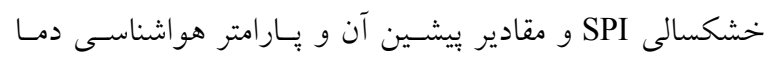
عملكرد بهترى را در بهبود مدلسـازىهـا دارا بودنــد. ميـانخين بارش نيز ضعيفترين عملكرد را نشان داد كه ايسن امسر ممكـن است به سبب وجود تغييرات ناخهانى در مقادير دادهها و تعـدد مقدار كمينه (صفر) در آمار بارش باشد.
هر يارامتر به سرى تاريـخى آن اضافه شدند و بـهـعنـوان ورودى به مدل انتخاب شده معرفى گرديدند. بـ از مدل ملسازى، مقــدار شاخص خشكسالى SPI در زمان l+t براى rإ آ ماه آينده (فوريه

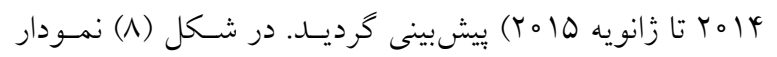
اين مقادير نشان داده شده است.

در اين بززوهش، سعى بر اين بود كه مـدلهــاى مناسـبى جهـت

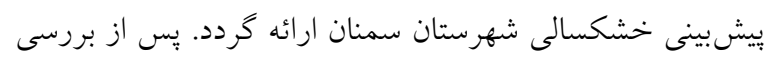
تمامى روشهاى مدلسازى، با تك تـى يارامترهـاى ورودى و

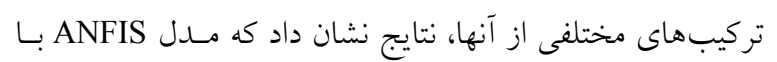

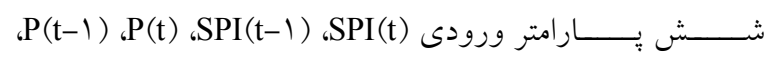

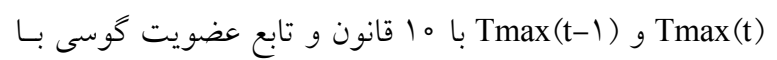

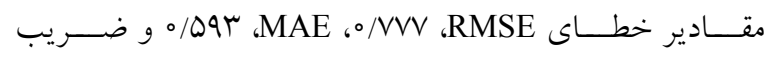

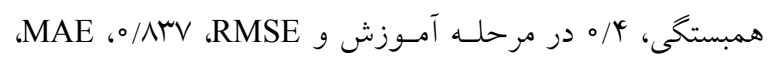

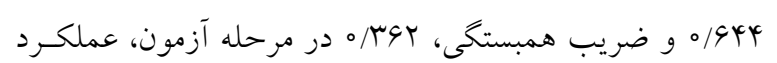
مناسبترى را دارا بود. يُ از ارزيسابى روشهـاى مــلـسـازى

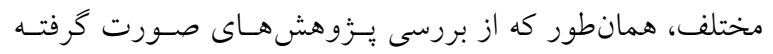

منابع مورد استفاده

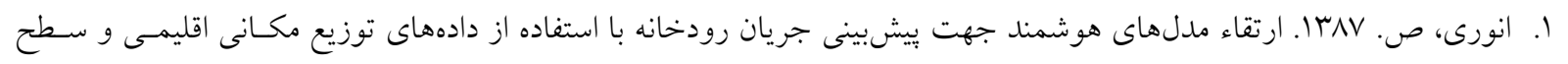

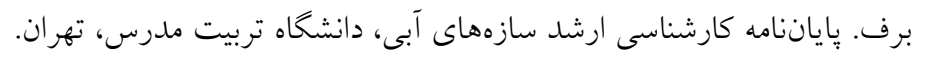




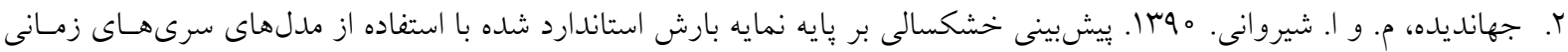

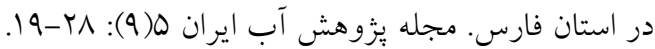

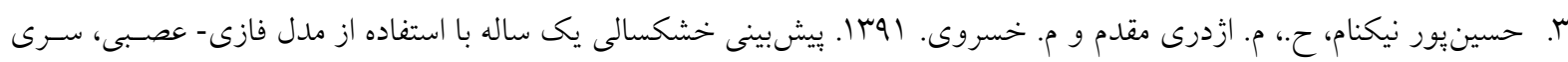

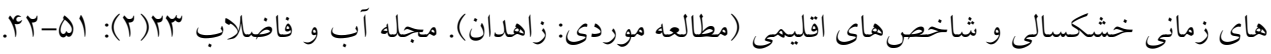

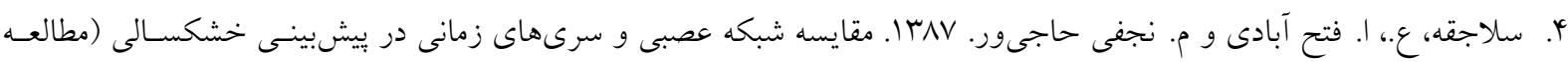

$$
\begin{aligned}
& \text { موردى: استان خر اسان رضوى). مجله علوم و مهندسى آبخيزدارى ايران Y(Y): }
\end{aligned}
$$

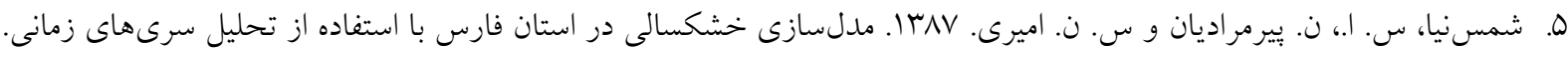

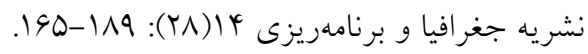

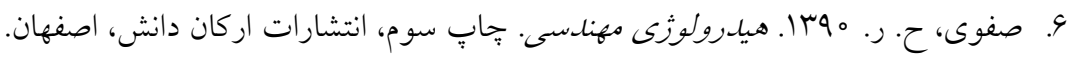

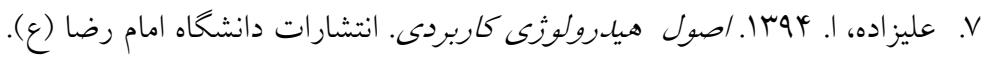

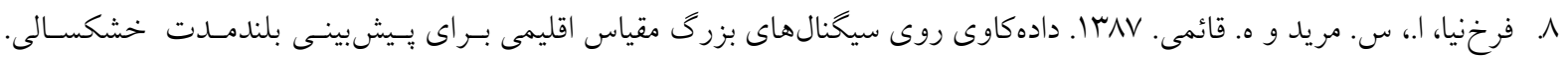

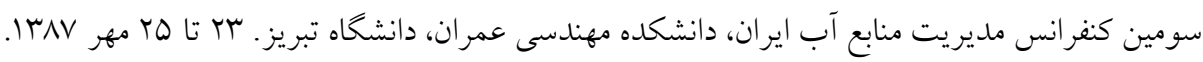

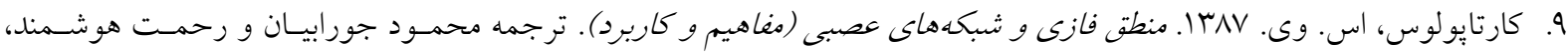

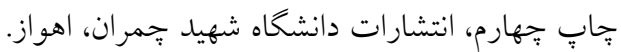

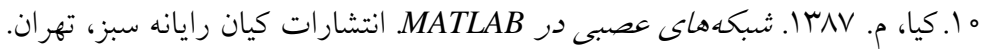

11. Barua, S. and B. J. C. Perera. 2012. Artificial neural network-based drought forecasting using a nonlinear aggregated drought index. J. Hydrol. Eng., ASCE 17: 1408-1413.

12. Box, G. E. P., G. M. Jenkins and G. C. Reinsel. 2002. Time Series Analysis: Forecasting and Control. Fourth Edition, John Wiley Publication, 734 p.

13. Crespo, J. L. and E. Mora. 1993. Drought estimation with neural networks. J. Adv. Eng. Software 18(3): 167-170.

14. Jalili, M., J. Gharibshah, S. M. Ghavami, M. R. Beheshtifar and R. Farshi. 2013. Nationwide prediction of drought conditions in Iran based on remote sensing data. IEEE Trans. Comput. 63(1): 90-101.

15. Jang, J. S. R. 1993. ANFIS: adaptive-network based fuzzy inference system. IEEE Trans. Sys. Man. Cyber. 23(3): 665-685.

16. Mason, J. C., R. K. Price and A. Tem'Me. 1996. A neural network model of rainfall runoff using radial basis functions. J. Hyd. Res. 34: 537-548.

17. McKee, T. B., N. J. Doesken and J. Kleist. 1993. The relation of drought frequency and duration to time scales. Preprints, $8^{\text {th }}$ Conference on Applied Climatology, 17-22 Jan. Anaheim, California, pp. 379-384.

18. Mishra, A. K. and V. R. Desai. 2005. Drought forecasting using stochastic models. Stoch. Environ. Res. Risk Assess. 19(5): 326-339.

19. Mishra A. K., V. R. Desai and P. Singh. 2007. Drought forecasting using a hybrid stochastic and neural network Model. J. Hydrol. Eng. 12(6): 626-638.

20. Morid, S., V. Smakhtin and K. Bagherzadeh. 2007. Drought forecastingusing artificial neural networks and time series of drought indices. Int. J. Climatol. 27(15): 2103-2111.

21. Ozger, M., A. K. Mishra and V. P. Singh. 2010. Estimating Palmer drought severity index using a wavelet fuzzy logic model based on meteorological variables. Int. J. Climatol. 31: 2021-2032.

22. Rezaee, A. 2001. Modeling flood and drought using artificial neural networks (ANN). Proceedings of the First National Conference in Water Crisis, 8-9 March, Zabul University, pp. 247-256. 


\title{
Selection of a Proper Model to Predict Monthly Drought in Semnan Using Weather Data and Linear and Nonlinear Models
}

\author{
M. Sadeghian, H. Karami* and S.F. Mousavi ${ }^{1}$
}

(Received: Dec. 27-2015 ; Accepted: Jan. 07-2017)

\begin{abstract}
Nowadays, greater recognition of drought and introducing its monitoring systems, particularly for the short-term periods, and adding predictability to these systems, could lead to presentation of more effective strategies for the management of water resources allocation. In this research, it is tried to present appropriate models to predict drought in city of Semnan, Iran, using time series, adaptive neuro-fuzzy inference system (ANFIS) and artificial neural networks (MLP and RBF). For these modeling processes, average monthly meteorological parameters of rainfall, temperature, minimum temperature, maximum temperature, relative humidity, minimum relative humidity, maximum relative humidity and SPI drought index were used during the period 1966 to 2013. The results showed that among the many developed models, the ANFIS model, with input data of average rainfall, maximum temperature, SPI and its last-month value, 10 rules and Gaussian membership function, showed appropriate performance at each stage of training and testing. The values of RMSE, MAE and R at training stage were 0.777, 0.593 and 0.4, respectively, and at testing stage were $0.837,0.644$ and 0.362 , respectively. Then, the input parameters of this model were predicted for the next 12 months using ARIMA model, and SPI values were predicted for the next 12 months. The ANN and time series methods with low difference in error values were ranked next, respectively. The input parameters SPI and temperature had better performance and rainfall parameter had weaker performance.
\end{abstract}

Keywords: Adaptive neuro-fuzzy inference system, Artificial neural network, Prediction of drought, Time-series.

1. Dept. of Water Eng. and Hydraulic Struc., Faculty of Civil Eng., Semnan Univ., Semnan. Iran.*: Corresponding Author, Email: hkarami@semnan.ac.ir 